\title{
A GREEN INVESTMENT
}

\section{If growing forests in India can generate lucrative carbon credits, then why isn't everyone planting trees? Paroma Basu reports.}

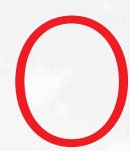

n a humid morning in August 2008, Harshkumar Kulkarni strolled through a thicket of young eucalyptus trees, surveying their slender forms. Stroking each silver trunk as he passed, Kulkarni, the general manager for plantations at the conglomerate Indian Tobacco Corporation (ITC), seemed like a concerned father checking on his children - albeit more than 3 million of them.

Kulkarni has spent the better part of two decades breeding fast-growing, diseasetolerant varieties of eucalyptus, leucaena and casuarina trees that can survive in the swampy, inhospitable soils of Khammam district, in India's southeastern state of Andhra Pradesh. Farmers who had struggled to grow traditional crops such as cotton can now earn up to US $\$ 500$ per hectare from timber that they sell to paper mills, including the one owned by the ITC.

But for the past few years, Kulkarni has been grooming some of his trees for a new role: carbon offsetting. Kulkarni and his colleagues realized that they might benefit from the global carbon market established in 2001 as part of the Kyoto Protocol. The Clean Development Mechanism (CDM) is a system by which participating countries can meet some of their greenhouse-gas reductions by buying certified carbon credits from projects in developing countries that reduce emissions. Kulkarni decided to devote a portion of the ITC's plantations to supplying those credits.
Seven years, mountains of paperwork and almost $\$ 70,000$ of the company's funds later, the project is set to become one of only two forestbased CDM projects in India - and one of only a handful in the world - to win the necessary approval from the United Nations Framework Convention on Climate Change (UNFCCC). If it is approved as expected in the next few months, families will be paid $\$ 65$ per year for each hectare they commit to grow for four years rather than logging every year. The owners still get money from timber sales when the trees are logged, as long as they immediately replant the plot. Kulkarni considers the project one of his biggest triumphs - but the past seven years have been difficult. "I lost 11 kilos and ruined my health trying to get this CDM project registered," he says.

India should be thick with forestry carbon-offset schemes: it was one of the first nations to move aggressively into carbon offsetting, has robust forestry policies and has vast swaths of land that could be planted. The challenge for Kulkarni and others trying to establish CDM forestry projects has come from the convoluted, expensive and bureaucratic approval process. Some of the biggest difficulties lie in documenting how much carbon the growing trees will absorb. Piecing together the patchwork of land involved is hard too; the 3,070 hectares in Kulkarni's project is owned by around 3,000 local tribal families. "Forest-based CDM has not yielded the desired results so far," says a high-ranking forestry official in India's Ministry of Environment and Forests, who did not want to be named. "The required methodologies and calculations are too complex and the costs are too high to justify. There is certainly huge scope to simplify the whole business."

Despite the complex system, India and other countries are keen to grow more forests for carbon credits. Those efforts that plant native trees could aid biodiversity conservation, and all such schemes can provide a potential source of income for impoverished families who depend on forests for their livelihoods. Soyam Nagamani, a community leader of the Koya tribe in Khammam district's Bhimavaram village, says that ever since she switched from growing traditional cotton crops to the ITC's eucalyptus trees, a lot more money has come in from the sale of timber. Now the promise of additional income has convinced her to devote a portion of her land to carbon offsetting. "We don't understand that much [about global warming]," says Nagamani, "but before we ate only two small meals a day whereas now we eat three full meals of rice."

\section{Grand potential}

India is among the most densely forested countries in the world and already has robust conservation policies requiring that trees are replanted as they are removed. Some $24 \%$ of the country's land mass is now forested, with the government aiming to reach up to $33 \%$ by 2012 . India also has vast stretches of land degraded by agriculture, development and pollution, plus remote and uncultivable lands, all of which could be planted with trees. It is here that the CDM could make a big difference. Project developers and forest-dependent 
communities now have an economic reason to plant and preserve trees. "Through the CDM, we need to create situations in which a standing tree makes more business sense than a felled tree, for only then will poor communities retain the tree," says Mohit Gera, a government forestry officer who has carried out research at the Energy and Resources Institute in New Delhi. "In developing countries such as India, carbon sequestration and poverty alleviation must happen side by side."

Trees can only ever be a temporary carbon sink. They will eventually release all their carbon when they die from old age, if not before, because of logging, fires, pests, floods or cyclones. "I feel that in forestry projects you are not actually mitigating climate change but just 'buying' time, or postponing the problem, because of the non-permanence issue," says José Domingos Miguez, a member of the UN's CDM executive board and an adviser on climate change in Brazil's ministry of science and technology. But forestry projects are still considered to be valuable as temporary 'carbon banks' that soak up greenhouse gases until researchers work out ways to make longer-lasting emissions cuts.

When the CDM was formally established, some expected forestry schemes to thrive because tree-planting is a relatively cheap and easy way to mitigate emissions compared with establishing a wind farm or hydropower plant. But although the incentives are there, few projects have materialized. Only one, in China's Pearl River basin, has received the green light from the UNFCCC. Around 25 more are awaiting final approval, according to UNFCCC figures: six in India (see map, overleaf), five in China and the rest scattered through Asia, Africa and South America. By contrast, the organization has approved 1,270 schemes worldwide - including 378 in India, more than any other country - to offset carbon in other sectors, ranging from wind farms to the destruction of non- $\mathrm{CO}_{2}$ greenhouse gases.
China's Pearl River project aims to reforest 4,000 hectares of watershed areas along the Pearl River basin in Guangxi province and to generate around 600,000 carbon credits by 2036 . It was an inspiration for the Indian forestry community, but it also exposed serious bottlenecks in the system, says Promode Kant, a former forestry official and director of the Institute of Climate Change and Ecology in New Delhi. Kant learned this first-hand as a technical adviser to a small, 370-hectare reforestation project in the north Indian state of Haryana that is, along with Kulkarni's project, on the brink of getting UNFCCC approval for carbon offsetting.

\section{Contrasting fortunes}

Where the Pearl River project enjoyed full government support - including a multimillion-dollar budget and the contribution of its mostly government-owned land — the Haryana scheme received none. The project was funded with less than $\$ 75,000$ by the state's cash-strapped forestry department, and Kant and his colleagues had to corral together 227 farmers across many villages, each owning tiny patches of a hectare or less. State forest departments ought to be the most enthusi-

\section{"In developing countries, carbon sequestration and poverty alleviation must happen side by side." - Mohit Gera} offsetting, but they lack financial resources and the experience to compile complicated project applications, says Jagdish Kishwan, directorgeneral of the government's Indian Council of Forestry Research and Education.

There are a number of bureaucratic hurdles to forest-based carbon offsetting. Many of them arise from the UNFCCC's stringent approval process. Before they can sell carbon credits, potential CDM projects have to pass through three rounds of evaluation: a government task force in the home nation, an audit of methodologies, finances and documentation by a UN-accredited body, and a final review by a CDM executive board staffed by scientists and officials.

After the CDM executive board was established in 2001, Indian entrepreneurs moved aggressively into the carbon-trade business and an industry of domestic and international carbon-consulting firms soon emerged to help Indian clients prepare technically sound projects in renewable energies and other areas. But the same is not true for forestry. The CDM guidelines for the forestry sector weren't figured out until 2003, two years after other emissions-reducing sectors, says Martin Schröder, lead auditor for forestry projects at TÜV SÜD Industrie Service in Munich, Germany, a UN-accredited firm that evaluates CDM projects. "Very few consultants are actually experienced in the field, so there are more project developers who are trying to make a go of it on their own," says Schröder. "They are discovering the hard way that the process is not so easy, because UNFCCC rules [for forest-based schemes] are rather complex, maybe even more complex than regular CDM projects."

One of the complexities lies in documenting - to the UNFCCC's satisfaction - how much carbon a forest will actually store for the duration of a project. Different tree species take up carbon at different rates and store it for varying amounts of time, depending on lifespans and harvesting cycles. Although researchers have fairly good estimates for these figures, it has been challenging for people such as Kulkarni, who are going it alone, to apply the CDM's methods on the ground. To ensure he made all of his calculations accurately, Kulkarni spent a lot of time travelling to conferences, reading scientific papers and consulting with CDM specialists, climate scientists and forestry researchers. But Miguez says that such an involved approval 
process is unavoidable. "The complexity of this type of project is necessary to guarantee that uptake of $\mathrm{CO}_{2}$ from the atmosphere is real and measurable," he says.

Managers of carbon-offset ventures must also meticulously account for 'leakage' - greenhouse gases that will be released into the atmosphere in the process of setting up the project. For example, a World Bank-funded reforestation project in the north Indian state of Himachal Pradesh had to account for emissions that would have been released by resident cattle, and would continue to be released when the cattle were moved elsewhere, along with those caused by land preparation, clearing bushes, petrol-burning trucks, water pumps and labourers.

More challenging, say proponents, is
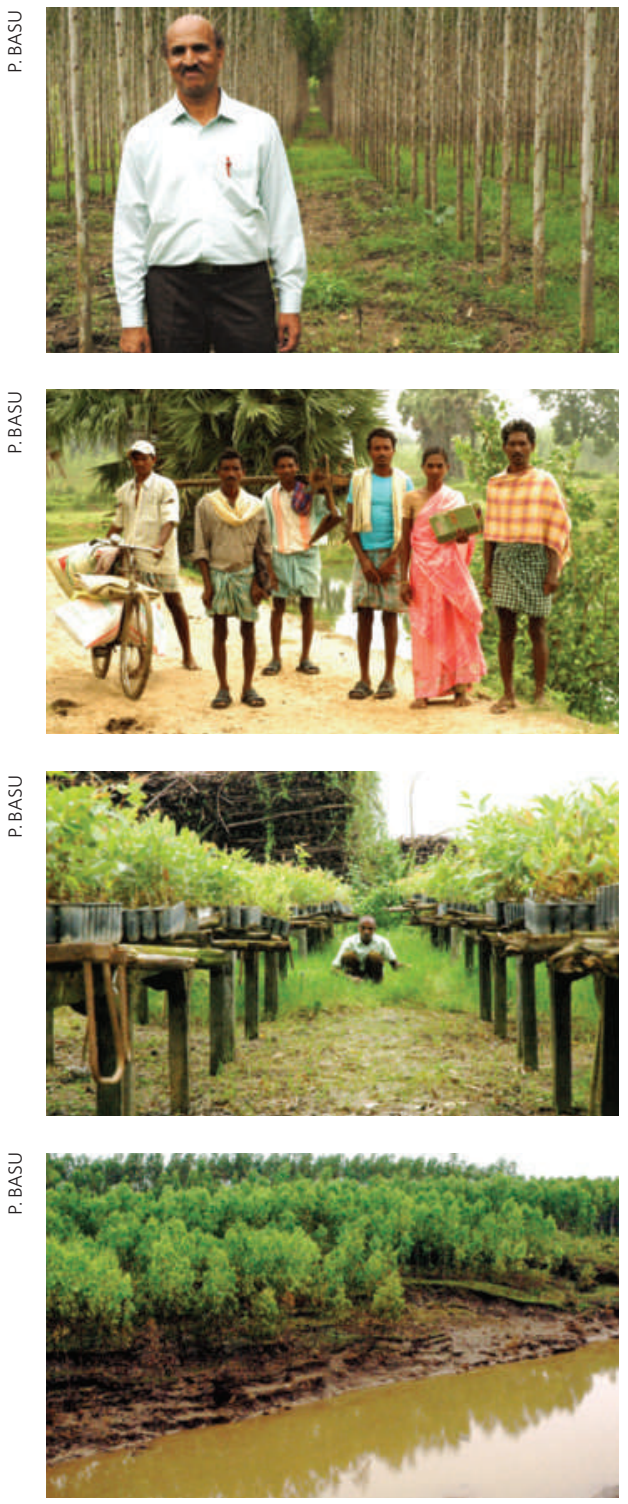

Harshkumar Kulkarni (top) is helping farmers in Khammam district to grow trees for carbon credits. demonstrating that projects meet the crucial 'additionality' concept, meaning that the greenhouse-gas reductions will be more than those that would have occurred anyway. As part of his application, Kulkarni had to prove that the land he wanted to plant on stood no chance of being otherwise reforested - by locals who own the land or by government 'social forestry' programmes - because the cost was too high and the soil so poor that it could support nothing but eucalyptus and other specially bred trees. Offset projects also have to describe the exact Global Positioning System coordinates for each of the land patches included, a job that, in India, must be contracted out to the only government agency that can produce such maps. This can cost thousands of dollars.

Even if Kulkarni and others do get approval for their projects, they cannot be sure of getting a good price for their carbon credits - or of finding buyers for them at all. This comes back to Miguez's 'non-permanence issue', the fact that the carbon in the forest will eventually be released, however many times it is logged and replanted. Because of their uncertain environmental value, forest-generated credits are expected to fetch only $\$ 4-\$ 5$ apiece in the global markets, compared with the \$20-\$23 fetched by carbon credits from other offset schemes. So far, only a few buyers, including Japan, Canada, Spain and the World Bank's BioCarbon Fund have expressed interest in buying these credits, and China's Pearl River project is yet to sell a single one.

\section{On the way to market}

Demand for forestry credits also remains low because the European Union does not yet allow their sale on its emissions trading system, or carbon stock exchange, ostensibly fearing that cheap forest credits would swamp the market and bring down prices. Miguez says this exclusion may be reconsidered during the next review by the system's governing committee, although it is still uncertain when that will be.

Kulkarni and other forestry managers are hoping that pricing issues and the other problems they have encountered will be ironed out in the post-Kyoto negotiations, so all eyes are on the 2009 Copenhagen talks, when discussions are expected to begin in earnest. Kant says he would like to see a simplification of the rules and regulations for forest-based CDM projects so that "the process becomes accessible to larger numbers of poor communities across the
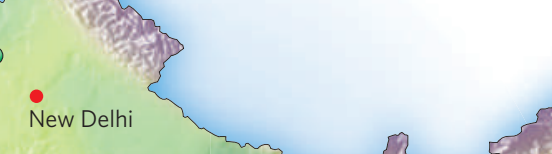

Andhra Pradesh and Orissa border

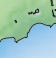

Chickballapur district
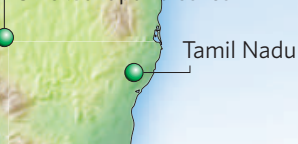

world through, for example, the

reduction of transaction costs. This is one area that has to be tackled and will be tackled."

Kant now conducts CDM training workshops for forestry officers in several developing countries and says that the situation is already improving. "I constantly used to hear that the CDM just can't be done," he says. "But now awareness and actual training efforts are growing, so there is increased understanding and confidence about the process." As many as six groups around India are currently in the early stages of planning forest offset schemes. Forestry managers still think that such ventures, with their UNFCCC stamp of approval, will provide an international, reputable business for the long term, says N. H. Ravindranath, an ecologist at the Indian Institute of Science, Bangalore, who serves on the government's CDM task force. "The whole CDM process is maybe a bit too rigorous, but it is generally the right way of doing projects as it is introducing accountability, encouraging community participation and trying to set good standards."

Kulkarni's experience in meeting those standards means that he is now in regular contact with others in the CDM community and has come to be known as something of an expert on forest-based carbon offsetting. "I still say the future [of forest offsetting] is bright in India," he says, "provided we line up simpler methods and practices."

On the ITC plantations, more and more farmers are agreeing to grow eucalyptus trees for carbon storage, persuaded by the additional income. But as for Kulkarni, he says that his motivations have changed. "By this point, earning money [from carbon credits] is not even the issue," he says. "We just want others to feel that if we can succeed, they can too." Paroma Basu is a freelance writer based in New Delhi, India. 